\title{
The Determinants of Export Performance: Evidence for Manufacturing Plants in Ireland and Northern Ireland
}

\author{
May 2004 \\ Stephen Roper and James H Love \\ Aston Business School \\ Aston University \\ Birmingham B4 7ET \\ Fax: +44 (0) 1213333474 \\ e-mail: s.roper@aston.ac.uk \\ j.h.love@aston.ac.uk
}

\section{Acknowledgements}

Over the years a large number of individuals have been involved in the collection of the dataset on which this paper is based. Particular thanks are due, however, to Nola HewittDundas (Queen's University Belfast). Data collection was financed by the Royal Irish Academy and the Industrial Research and Technology Unit, Belfast. Staff in the development agencies in both Dublin and Belfast generously provided access to sampling frames and expertise. Additional thanks are due to Maureen O'Reilly (Economic Research Institute of Northern Ireland) for providing access to the exports data for Northern Ireland and to Jessica Doyle for high quality research assistance. 


\begin{abstract}
The dramatic GDP and export growth of Ireland over the last decade forms a marked contrast with that of its nearest neighbour Northern Ireland. In Ireland, export volume growth averaged 15.5 per cent p.a. from 1991-99 compared to 6.3 per cent from Northern Ireland. Using data on individual manufacturing plants this paper considers the determinants of export performance in the two areas.

Larger, externally-owned plants with higher skill levels are found to have the highest export propensities in both areas. Other influences (plant age, R\&D etc.) prove more strongly conditional on location, plant size, and ownership. Structural factors (e.g. ownership, industry) explain almost all of the difference in export propensity between larger plants in Northern Ireland and Ireland but only around one third of that between smaller plants. Significant differences are also evident between plants in terms of their sources of new technology. For indigenously-owned plants, in-house R\&D is important. For externally-owned plants, R\&D conducted elsewhere in the group typically outside Ireland and Northern Ireland - proves more significant. This external dependency and lower than expected export propensity on the part of small plants in Northern Ireland represent significant policy challenges for the future.
\end{abstract}




\section{The Determinants of Export Performance: Evidence for Manufacturing Plants in Ireland and Northern Ireland}

\section{Introduction}

The dramatic GDP and export growth of Ireland over the last decade forms a marked contrast with that of its nearest neighbour Northern Ireland. In Ireland, export volume growth averaged 15.5 per cent pa from 1991-99 compared to 6.3 per cent from

Northern Ireland. Average real GDP growth from 1991 to 2000 in Ireland was 7.1 per cent pa compared to 2.7 per cent pa in Northern Ireland ${ }^{1}$. By 1997, this meant that GDP per capita in Northern Ireland continued to lag 18 per cent below the EU average while that in the Celtic Tiger economy of Ireland was 102 per cent of the EU average $^{2}$. What factors can explain these stark differences in performance given that Northern Ireland and Ireland share a common geographical situation, i.e. both are 'peripheral' to the main European markets?

Much speculation has, of course, already surrounded the causes of the 'Celtic Tiger' phenomenon in Ireland (e.g. Gray, 1997; Sweeney, 1998; Barry, 1999; Murphy 2000) with the general consensus focusing on the vital role of FDI and the growth of the externally-owned, high-tech sector (e.g. McCarthy, 1999; Ruane and Görg, 1997; Roper and Frenkel, 2000) $)^{3}$. Other factors have also been implicated, however, as explanations for differential trade performance. Barry and Bradley (1997), for example, emphasise the importance of market orientation and industrial sector to the success of the Irish economy. For Northern Ireland, perhaps the dominant focus of interest is the potential role of the Troubles in influencing export potential, although as Fielding (2003) highlights this is not the only factor which has been important. Indeed, while Fielding's evidence certainly suggests that the Troubles did have a

\footnotetext{
${ }^{1}$ Sources: Ireland, GDP volume growth average measure, Table 13, Budgetary and Economic Statistics, March 2001, Department of Finance; Northern Ireland, NIERC/OEF Regional Economic Outlook, Spring 2001.

${ }^{2}$ Marked disparities exist, however, between regions within Ireland. GDP per capita is around 112 per cent of the EU average in the Southern and Eastern region but only 75 per cent in the Border, Midlands and Western region. Source: Statistics in Focus, General Statistics, Theme 1-1/2000, Eurostat. ${ }^{3}$ Murphy (2000) describes the situation as follows: 'Ireland's transformation, one primarily caused by multinationals, was facilitated by the phenomenon of globalisation ... Globalisation enabled Ireland to move from the periphery towards the centre of the new global economy. Now Ireland is the second largest exporter of packaged software in the world after the US ... From having virtually no major export industries (Guinness and Irish whiskey representing two exceptions) Ireland has become a significant platform for US high-tech companies competing in the European market' (p. 4).
} 
negative effect on investment in Northern Ireland's manufacturing sector this was more than compensated by the positive effect of higher industrial subsidies, and the attractiveness of Northern Ireland as a production location for companies seeking to emigrate from Southern regions of the UK. The net result was that manufacturing employment and investment in Northern Ireland was actually sustained at a higher level than that in the UK as a whole over the 1971-96 period (Fielding, 2003, p. 514), although as Harris et al. (2002) and Roper and Hewitt-Dundas (2001) point out the effects of government assistance on productivity in Northern Ireland were less positive.

From a broader perspective, Greenhalgh (1990) and Buxton et al. (1991) consider the potential effects of non-price competitiveness on export performance, with Thirwall (1986) suggesting that it was failure to keep pace with rising quality standards in international markets that was a major factor in the UK's poor trade performance through to the 1980s. More recently, attention has focussed on the comparative trade performance of UK and German manufacturing firms (e.g. Wakelin, 1998; Anderton, 1999, 1999a; Roper and Love, 2002), suggesting that that non-price qualities proxied by innovation and R\&D indicators - are a potentially important explanation of differences in trade performance. In an Irish context, both Northern Ireland and Ireland have traditionally had low levels of R\&D investment, and a strong concentration of R\&D and innovation activity in externally-owned firms. Roper et al. (2002) suggest, however, that Northern Ireland firms lag somewhat behind firms in Ireland in terms of innovation and technology adoption, a factor which the evidence of Wakelin (1998) etc. would suggest might be having a negative effect on relative export propensity.

Other factors - including the potential influence of currency fluctuations - also differentiate the operating environment of firms in Northern Ireland and Ireland. Common to both areas, however, has been an emphasis on promoting export development through direct measures focussing on marketing, and indirect measures focussing on improving firms' international competitiveness (Seringhaus and Rossen, 
1990) ${ }^{4,5}$. Policy in both areas has focussed particularly on developing the export potential of indigenously-owned and smaller firms reflecting policy-makers' concerns of over-reliance on the export activities of MNE subsidiaries (Bell, 1997, p. 168) ${ }^{6}$.

The remainder of the paper is organised as follows. Section 2 provides the context, by profiling the development of export growth in Northern Ireland and Ireland since 1991. Section 3 outlines a simple conceptual model of export propensity, drawing together previous 'neo-endowment' and technology-based models (Wakelin, 1998). Section 4 then describes the data used and our empirical approach. Section 5 outlines the main empirical results, and section 6 concludes with a summary and policy discussion.

\section{Exports Growth During the 1990s}

The 1990s witnessed rapid growth in the volume of manufacturing exports from both Northern Ireland and Ireland (Figure 1). The more dramatic growth of export sales from Ireland was accompanied by marked changes in the composition of exports as the externally dominated, high-tech sector expanded rapidly (Table 1). From 1991-98, for example, foreign-owned firms accounted for 95 per cent of the growth in industrial exports from Ireland and at least 75 per cent of total export growth (Forfás, 2000, p. 9). Manufacturing firms' export propensity in Ireland also rose markedly over this period 'rising from an average of 73 per cent in 1991 to 83 per cent in 1998 ... export propensity was highest in the chemicals and electronic and optical equipment sectors at 97 and 93 per cent respectively' (Forfás, 2000, p. 23). As a result, exports of chemicals etc. (including pharmaceuticals) in Ireland grew from 19.5 per cent of total export sales in 1991 to 35.8 per cent by 1999. Similarly, electrical and optical equipment, which includes the manufacture of computers and

\footnotetext{
${ }^{4}$ Bell (1997), p. 148-149 quotes the definition of export promotion suggested by Seringhaus (1986), viz: 'all public policy measures that actually or potentially enhance exporting activity either from a firm, industry or national perspective'.

${ }^{5}$ From 1991-98 direct export promotion in Ireland was the primary responsibility of An Bord Tráchtála (or the ITB). In 1998 the ITB merged with Forbairt the agency responsible for the development of indigenous firms and innovation and the agency responsible for business training to form Enterprise Ireland. In Northern Ireland, before the consolidation of agencies into Invest Northern Ireland in 2002, trade promotion was primarily the responsibility of Trade International part of the IDB although the small business agency LEDU also encouraged export development.

${ }^{6}$ For example, specific policy initiatives are described in Mackinnon (1997) and Demick and O'Reilly, (2000)
} 
components, rose from 31.5 per cent of total exports sales in 1991 to 43.9 per cent by 1999 (Table 1).

While the rapidly expanding externally-owned sector in Ireland increased its export sales and re-oriented Ireland's industrial base towards faster growing regions and goods with higher income elasticities (Barry and Bradley, 1997), doubts remain about the international competitiveness of indigenously-owned firms in Ireland (e.g. Wrynn, 1997). For example, exports of indigenously-owned firms in Ireland grew more slowly over the 1991-98 period than over previous 1986-91 period (Forfás, 2000, p. $25)^{7}$. As a result, the share of Ireland's industrial exports made by indigenouslyowned firms fell from 26 per cent of the total in 1991 to 12 per cent by 1998 (Forfás, 2000, p. 9). This is also reflected in the sectoral composition of exports from Ireland. The food and drink sector, for example, accounted for a quarter of exports in 1991 but only a tenth by 1999 (Table 1). Other, more traditional, sectors (notably textiles and clothing) saw their export sales fall in both real terms, and as a share of total export sales (Table A3).

As in Ireland, externally-owned firms are also important in the Northern Ireland manufacturing sector. In 1996, for example, 18.3 per cent of employment, 29.8 per cent of value added and 24.6 per cent of net capital expenditure in Northern Ireland manufacturing was by firms owned outside the $\mathrm{UK}^{8}$. Other studies have suggested that a similar proportion of manufacturing activity in Northern Ireland may be accounted for by firms owned in other UK regions (e.g. Murshed et al., 1993, p. 54). In contrast to Ireland, however, the Northern Ireland externally-owned manufacturing sector is longer established, includes firms in more mature industries, and has a much larger UK-owned component (e.g. Crone, 1998) ${ }^{9}$. As a result, its export growth has been more like that of the indigenously-owned sector, and changes in the composition

\footnotetext{
${ }^{7}$ Using data derived from the Census of Industrial Production, Forfás (2000) estimates the export growth of indigenous Irish firms at 12.3 per cent pa between 1986 and 1991 and 4.4 per cent between 1991 and 1998. Commenting on this difference the report notes that 'the relatively poor measured export performance of the indigenous sector in the $1990 \mathrm{~s}$... may in part reflect the accelerating internationalisation of the Irish economy, with high numbers of Irish firms being acquired by foreign firms and investors. It may also be possible that indigenous firms have substituted domestic for foreign export sales to exploit faster demand growth in the home market'.

${ }^{8}$ Source: Tables 6 and 11, Manufacturing Production and Construction Inquiries - Summary Volume, PA 1002, National Statistics 1996.

${ }^{9}$ More recent investment into Northern Ireland has been dominated by software, networked services and back office activity (Crone, 2000)
} 
of Northern Ireland exports have been less dramatic than those in Ireland. The same fundamental trends are evident, however, in the Northern Ireland exports figures; expanding export sales of electrical and optical equipment and declines in the export shares of the more traditional textile and food-based sectors (Table 1).

\section{Conceptual Model}

Two main conceptual approaches exist to modelling the determinants of export performance (Wakelin, 1998): 'neo-endowment' models in which firms' competitive advantage is based on factor endowments and, 'technology-based' models in which competitive advantage derives from the quality of firms' products or services. Studies in the neo-endowment tradition argue that factor-based advantages may be important if the firm has either a natural monopoly of a particular factor or is, for example, located in a particular region where a factor is plentiful. Extending the more traditional range of factors included in such models beyond labour and capital to include different dimensions of human and organisational resources, emphasises the parallels between this type of explanation and resource-based models of company competitiveness. The argument then becomes one of identifying the types of productive resources that determine firms' competitive advantage in export markets. In terms of firms' internal resources, Wakelin (1998a) identifies positive links between export performance and average capital intensity among UK firms, while Sterlacchini (1999) identifies a positive relationship between the technological level of firms' capital stock and the export propensity of small Italian businesses. Roper and Love (2002) also emphasise the potential benefits of being part of a multi-plant group, finding that, in the UK at least, group-members were likely to have higher export propensity than similar single-plant businesses. Another common finding is a positive but non-linear relationship between export propensity and plant size, a variable which may itself be acting as a proxy for the strength of firms' resource base (Kumar and Siddharthan, 1994; Wagner, 1995; Bernard and Wagner, 1997; Wakelin, 1998a; Bernard and Jensen, 1999; Sterlacchini, 1999; Roper and Love, 2002) ${ }^{10}$.

\footnotetext{
${ }^{10}$ The findings of Bernard and Wagner (1997) and Bernard and Jensen (1999) suggest that large and strong plants/firms tend to become exporters, rather than exporting enhancing performance.
} 
Technology-based models of export performance focus primarily on firms' investments or achievements in implementing new technologies, or the development of new products or processes. This capability will depend on the internal strengths of the plant, where applicable its links to other group companies, and on the support available from the regional or national innovation system within which the firm is operating (Nelson, 1993; Metcalfe, 1997). The presence of an R\&D function within a plant, for example, may stimulate innovation through the type of technology-push process envisaged in linear models of innovation. R\&D staff may also, however, contribute to firms' creativity as part of multi-functional groups, or may allow firms to utilise extra-mural networks or information sources more effectively (Veugelers and Cassiman, 1999; Love and Roper, 2001). Braunerhjelm (1996), for example, provides evidence from Sweden that R\&D expenditures and investment in skilled labour both have a positive effect on firms' export intensity, while more conventional cost factors have no effect. For plants which are part of multi-plant groups, access to group-wide R\&D resources may also be important sources of new technology and product innovation. The Irish operations of US software multi-nationals, for example, are strongly dependent on the transfer of technology from software development centres within the US (Coe, 1997).

Taking into account the findings of previous studies in both the neo-endowment and technology-based traditions, our model of export propensity will include a number of indicators of plants' operating and organisational characteristics. In particular, we allow for the ownership characteristics of plants and, where appropriate, for the presence elsewhere of group R\&D facilities. Given the differences in policy and economic performance between Northern Ireland and Ireland we also allow for plant location. This suggests a basic model of the form:

$$
X_{i t}=\beta_{0}+\beta_{1} R_{i t}+\beta_{2} C_{i t}+\beta_{3} L_{i}+\beta_{4} S_{i}+\varepsilon_{i t}
$$

Where: $\mathrm{X}_{\mathrm{it}}$ is the export propensity (i.e. the share of exports in total sales) of plant $\mathrm{i}$ in period $t, R_{i t}$ is a set of indicators of plants' internal resource endowments, $C_{i t}$ is a set of plants' other characteristics, $\mathrm{L}_{\mathrm{it}}$ is an indicator of potential locational effects and $\mathrm{S}_{\text {it }}$ is a vector of sectoral indicators. 


\section{Data and Estimation Methods}

The data used is taken from the $2^{\text {nd }}$ and $3^{\text {rd }}$ surveys in the Irish Innovation Panel (IIP), a series of surveys of innovation activity by manufacturing plants with 10 or more employees (Roper et al, 1996; Roper and Hewitt-Dundas, 1998; Roper and Anderson, $2000)^{11}$. Each survey was undertaken by post using a sampling frame provided by the economic development agencies in Northern Ireland and Ireland. The second IIP survey was conducted between November 1996 and March 1997, covered plants' innovation activity during the 1994-96 period, and had a response rate of 32.9 per cent (Roper and Hewitt-Dundas, 1998). The third IIP survey, covering the 1997-99 period, was undertaken between October 1999 and January 2000 and achieved an overall response rate of 32.8 per cent (Roper and Anderson, 2000). 344 plants responded to both the $2^{\text {nd }}$ and $3^{\text {rd }}$ IIP surveys, with a further 1,119 plants responding to one of the two surveys (Table 2). Single observations included in the unbalanced panel relate to plants which responded to only one of the surveys either because of non-response or because the plant was newly opened or had closed at the other survey date. In terms of employment in the target group (i.e. manufacturing plants with more than 10 employees) the IIP panel covers 32.2 per cent in 1996 and 36.4 per cent in $1999^{12}$.

As part of each of the surveys, plants were asked about their export propensity and also provided a range of background information on the plant itself (Table 3). Export propensity is measured by the proportion of plants' sales made outside the UK and Ireland, i.e. sales in continental Europe and beyond. This measure was chosen for two main reasons. First, given the context for this study (i.e. covering Northern Ireland, a

\footnotetext{
${ }^{11}$ One unfortunate feature of the IIP in terms of the current analysis is a change in the definition of the 'export propensity' variable after the first survey. In 1993, plants were asked to indicate the proportion of their sales which were exported whereas in the latter two surveys plants were asked to indicate the proportion of their sales made outside the UK and Ireland.

${ }^{12}$ The target population was estimated from the Census of Industrial Production for Ireland (Table 3) for 1996. For 1999 the target population was estimated using total manufacturing employment (Source: Table 45 Budgetary and Economic Statistics, Dept of Finance) and the 1996 proportion of total employment in the target group. For Northern Ireland, data for 1993 is available from the Size Analysis of UK Business, 1993, Table 10. For subsequent years total manufacturing employment is taken from the Northern Ireland Annual Abstract, 2000, Table 8.5 and adjusted using the 1993 proportion of manufacturing employment in plants with less than 10 employees. Sample coverage in Northern Ireland (and Ireland) was in: 1996, 35.6 per cent (30.8 per cent); 1999, 49.2 per cent (31.1 per cent).
} 
region of the UK and a national economy, Ireland) this definition has the advantage of avoiding any ambiguity over the definition of exports. Secondly, it provides a common basis for comparison between the export performance of plants in Northern Ireland and Ireland. The disadvantage of this measure is that it excludes sales made by plants in Northern Ireland and Ireland in each others home markets and in Great Britain. The former exclusion is perhaps the least objectionable given the different relative sizes of the Northern Ireland and Ireland markets. The latter is more difficult but is justified on the basis that for Northern Ireland firms, GB is part of the UK home market whereas for firms in Ireland it represents an export market. Including sales in GB in the analysis would therefore lead to an uneven comparison between the apparent export competitiveness of plants in Northern Ireland and Ireland. In terms of the chosen measure - export sales outside the UK and Ireland - export propensity among Irish plants averaged 30-35 per cent compared to 16-18 per cent among Northern Ireland plants (Table 3).

Four groups of potential determinants of export propensity are considered relating to: plants' internal resource base; other plant characteristics; the location of the plant; and, the sector in which the plant is operating. The first of these groups of determinants of export propensity included in equation 1 relates to the strength of plants' internal resource base. Central to this is whether the plant conducts informal $R \& D$ in house, has an organised R\&D department or, where applicable, has access to R\&D conducted elsewhere in the group. Essentially similar proportions of plants in Northern Ireland and Ireland undertake informal R\&D (27-28 per cent), but larger proportions of Irish plants both have formal R\&D departments and access to group R\&D (Table 3). Previous studies provide strong evidence that R\&D capability contributes to plants' export competitiveness. We expect, therefore, that for any given set of plant characteristics, the effect of $R \& D$ on exporting is likely ceteris paribus to be positive. Essentially similar arguments suggest that we would also expect to observe a positive relationship between variables representing the quality of plants' human resource base and export performance.

Plant size is also generally expected to have a positive relationship to export propensity as larger plants have more resources with which to enter foreign markets. Wakelin (1998a) argues, for example, that this may be particularly important if there 
are fixed costs to exporting such as information gathering, or economies of production and/or marketing which may benefit larger firms disproportionately. Scale may be important in overcoming such initial cost barriers but may then be less significant in determining the extent of firms' export activity. Support for this assertion comes from the non-linear relationship between plant size (employment) and export propensity found by Kumar and Siddharthan (1994), Willmore (1992), Wakelin (1998a) and Sterlacchini (1999), each of which identifies an inverted-U shape relationship. We therefore include both plant size and its square in the estimated models, and expect to find a quadratic relationship with export propensity.

Other potentially relevant plant characteristics include business age, whether or not the plant is locally or externally-owned, and the type of production being undertaken. Business maturity in the Irish electronics sector, for example, has been shown by Görg and Ruane (2000) to lead to stronger local linkages and greater local sourcing. Similar arguments may be applicable to the relationship between plant-vintage and export propensity. Older plants may have had time to establish and expand their distribution networks, and also to establish a market position in export markets. We might therefore expect a positive coefficient on the plant age variable. Ownership may also be an important indicator of a plant's export potential if it is able to take advantage of group resources for branding, marketing or distribution. As indicated earlier, the export sales of Ireland's externally-owned sector has increased much more rapidly than that of indigenously-owned plants over the last decade (Forfás, 2000). This, and the strong export orientation of much inward-investment to both Northern Ireland and Ireland, suggests we would expect a positive relationship between external-ownership and export propensity. In aggregate, this effect is likely to be stronger in Ireland given the much larger proportion of externally-owned plants (Table 3).

In terms of plants' production activities, we include two indicators relating to small and large batch production. Small batch production may be associated with either a product differentiation strategy, or a focus on niche markets. Large batches are more likely to reflect commodity production for broader geographical markets and may therefore be more strongly associated with exporting. We therefore expect a negative relationship between small batch production and export propensity and a positive 
relationship between large batches and exporting. These effects are likely to be equally important in both Northern Ireland and Ireland as the profile of production activities of plants in both areas is broadly similar (Table 3).

In the estimation the form of the dependent variable - export propensity - is expressed as a percentage of total sales, suggesting the appropriate estimator is Tobit. Two issues arise in using Tobit models, however. First, there is no standard counterpart to the $\mathrm{R}^{2}$ measure of fit. Alternatives have been reviewed, however, by Veall and Zimmermann (1994) and we report two such measures which conform to both of Veall and Zimmermann's desirable criteria for pseudo- $\mathrm{R}^{2}$ measures in Tobit; the ability to mimic the numeric properties of the standard $\mathrm{R}^{2}$ statistic in OLS, and being based on the full sample of both censored and non-limit observations. If $\hat{y}_{i}$ is the predicted value then these are defined as follows (Greene, 2002, p. E21-12):

$$
R_{\text {ANOVA }}^{2}=\frac{\frac{1}{n} \sum_{i=1}^{n}\left(\hat{y}_{i}-\overline{\hat{y}}\right)^{2}}{\frac{1}{n} \sum_{i=1}^{n}\left(y_{i}-\bar{y}\right)^{2}}
$$

and

$$
R_{D E C O M P}^{2}=\frac{\frac{1}{n} \sum_{i=1}^{n}\left(\hat{y}_{i}-\bar{y}\right)^{2}}{\frac{1}{n} \sum_{i=1}^{n}\left(\hat{y}_{i}-\bar{y}\right)^{2}+\frac{1}{n} \sum_{i=1}^{n}\left(y_{i}-\hat{y}_{i}\right)^{2}}
$$

The first measure is the variance of the estimated conditional mean divided by the variance of the observed variable. The second measure is the ratio of the variance of the conditional mean around the overall mean of the data to the same measure, plus the residual variance, in the denominator.

The second issue which arises when using Tobit models is the choice of predicted values given the possibility that any randomly drawn observation may take a limit value. Two possible avenues are open; to choose a predicted value which is computed only from non-limit observations, or to choose a computation which reflects the likely value of an observation drawn at random from the population whether censored or not. In the current context where the proportion of exporting firms may differ between groups of firms or areas, the latter option is most attractive reflecting both the 
likelihood of plants not exporting and their export propensity, and we therefore compute predicted values as follows

$$
E\left(y_{i}, x_{i}\right)=\Phi\left(\beta^{\prime} x_{i} / \sigma\right)\left(\beta^{\prime} x_{i}+\sigma \lambda_{i}\right)
$$

where $\lambda_{i}=\phi\left(\beta^{\prime} x_{i} / \sigma\right) / \Phi\left(\beta^{\prime} x_{i} / \sigma\right), \Phi$ is the standard normal cdf, and $\varphi$ is the standard normal pdf (Greene, 1999, p. 694).

\section{Empirical Analysis}

Before considering the determinants of export propensity it was necessary to identify the appropriate level of geographical and temporal aggregation .A combined Tobit model was therefore estimated for all plants in the $2^{\text {nd }}$ and $3^{\text {rd }}$ IIP surveys ${ }^{13}$. Wald tests were then carried out and the hypothesis of equality of the estimated parameters between the 1994-96 and 1997-99 periods could not be rejected, and therefore in all reported results the two time periods are pooled ${ }^{14}$. Wald tests also indicated, however, that it was invalid to pool the Northern Ireland and Ireland samples, and so separate estimations are shown for each geographical area. In addition to the aggregate results we also report results for two split samples: indigenously-owned and externally-owned plants, and plants of different sizes. In all case the sample split is justifiable in terms of an appropriate Wald test.

\subsection{Whole Sample Results}

The first notable feature of this model is the strong positive effect on export propensity of the strength of plants' internal resource base, and the similarity between plants in Northern Ireland and Ireland in this respect (Table 4). Plants with a high proportion of graduate employees had higher export propensity, as did plants with an in-house $R \& D$ capability. Both $R \& D$ conducted informally and $R \& D$ conducted in a formally organised R\&D department contribute to increased export propensity, with more structured R\&D activity having a larger positive effect in both areas. This may reflect the more systematic exploitation of $R \& D$ resources in a structured setting, or

\footnotetext{
${ }^{13}$ Initial experimentation also involved models including indicators of innovation and sectoral, locational and supply-chain spillovers following Roper and Love (2002). These variables proved universally insignificant in the estimation and are therefore omitted from the results reported.
} 
the likelihood that plants with formally organised R\&D departments are actually making larger R\&D investments. These positive results for $R \& D$ reflect those found in other studies in the technology-based tradition which also suggest a strong positive relationship between $\mathrm{R} \& \mathrm{D}$, interpreted as a proxy for the non-price competitiveness of products, and export propensity (e.g. Wakelin, 1998; Anderton, 1999, 1999a). Notably, for the sample as a whole, however, access to R\&D conducted elsewhere within each plant's group has an insignificant effect on export propensity. Plant size which we interpret as a general indicator of the strength of plants' resource base - also proves important, and we observe the expected quadratic relationship between export propensity and employment (see also Kumar and Siddharthan,1994; Willmore, 1992; Wakelin, 1998a; Sterlacchini,1999; Roper and Love, 2002).

Other plant characteristics also prove important in determining export propensity in the combined sample (Table 4). External ownership in particular has a strong positive effect in Ireland, reflecting its position as a production base from which US high-tech firms serve the European or EU markets (Roper and Frenkel, 2000). The significance of the 'large-batch' variable in Ireland is also suggestive of a similar interpretation, reflecting the large relative size of most externally-owned manufacturing plants in Ireland ${ }^{15}$.

Marked differences are also evident between areas in terms of the impact on export propensity of the age of the plant. In Northern Ireland we observe the expected age effect, with older plants having higher export propensity ceteris paribus. This is consistent with the hypothesis that older plants are more likely to have better developed export market positions or distribution networks which might increase export propensity. In Ireland, however, the opposite is true, with higher export propensity among younger plants. One clear possibility is that this contrast reflects the diverse industrial history of the two areas outlined earlier. In Northern Ireland, there has been relatively little inward investment by Irish standards over the last decade, and the positive coefficient on plant vintage is consistent with the steady development by plants of their export market position and hence export propensity. Such organic

\footnotetext{
${ }^{14}$ Wald statistics for equality of coefficients are shown separately in each table of results.

${ }^{15}$ On average in the Irish Innovation Panel, externally-owned plants in Ireland had 204 employees compared to 46 employees in indigenously owned plants.
} 
developments are also likely to have taken place in Ireland as Görg and Ruane (2000) suggest but their effect is perhaps dominated by the massive scale of recent and highly export-oriented inward investment. This is also suggested by the very much larger and statistically stronger positive coefficient on the variable denoting external-ownership in Ireland (Table 4), a contrast discussed in more detail in the next section.

\subsection{Indigenously and Externally-Owned Plants}

Forfás (2000) and other commentators on economic development in Ireland have emphasised the importance of inward investment in the Celtic Tiger phenomena, and the very different export record of indigenously and externally-owned plants. A potentially interesting decomposition of the sample is therefore to consider whether the determinants of export propensity are markedly different for indigenous and externally-owned businesses. Tables 5 and 6 report separate Tobit models for the export propensity of indigenously and externally-owned plants ${ }^{16}$. As expected these models do suggest significant differences between the determinants of export propensity for the two groups of plants as well as differences between the Northern Ireland and Ireland samples.

For indigenously-owned plants (Table 5) the insignificance of the Northern Ireland dummy suggests there is no significant difference between the export propensities of indigenous plants, North and South. However, the Wald tests indicate clearly that the samples cannot be pooled, suggesting that the determinants of export propensity differ between the two areas. One major difference is the effect of plant vintage, where the results echo those of the whole sample (cf. Table 4). This means differences in the effect of plant age on export propensity are not restricted to externally-owned plants, but apply with equal force to the indigenous sector. The suggestion is that, as O’Malley (1998) suggests, newer indigenously-owned firms in Ireland have overcome some of the limitations of limited internationalisation highlighted by earlier studies such as Foley and Griffiths (1992).

\footnotetext{
${ }^{16}$ A Wald test of the equality of the estimated coefficients for locally and externally-owned plants in the whole sample model is $\chi^{2}(19)=151.82(\rho<0.000)$. This, of course, has implications for the validity of pooling the Northern Ireland and Irish samples in Table 4. However, there is clearly interest in seeing the overall pattern of export determination in the two areas, not least from a policy perspective.
} 
For externally-owned plants (Table 6) the Northern Ireland sample is small, itself a reflection of the contrasting inward investment experience of the two areas. Here, the contrasts between Northern Ireland and Irish plants is much stronger, reflected in the significant Northern Ireland dummy and the much more significant Wald test statistics. For example, in Northern Ireland the group R\&D coefficient is highly significant while plant size matters little. By contrast, for externally-owned plants in Ireland there is little evidence of any strong link between $R \& D$ and exporting and, as before, a significantly negative age effect. Notably, however, labour quality (indicated by the proportion of graduates in the workforce) is an important export determinant in the South but not in the North. Finally, the sectoral dummies are more significant in the equations for externally-owned plants than in those for indigenously-owned businesses highlighting larger sectoral differences in export performance among externally-owned than among indigenously-owned plants.

For Northern Ireland our results suggest a picture of indigenously-owned plants competing in international markets on the basis of their internal competencies, while externally-owned plants derive their international competitiveness not so much from their internal capabilities but from R\&D conducted elsewhere. Intriguingly, this configuration of plants' sources of international competitiveness reflects closely that in other accounts of the Irish manufacturing sector (e.g. Yearly, 1995; Wyrnn, 1997). However, our results indicate that - at least in terms of export propensity - this picture is much more typical of Northern Ireland than of Ireland. Export propensity in Irish plants is instead more dependent on the character of the production operation itself, particularly scale, plant vintage and the quality of the plants' human resource.

\subsection{Small and Larger Plants}

From a policy perspective another interesting distinction is that between the factors which determine export propensity in small and larger plants. Promoting exporting among small firms has been a particular focus of policy in both areas and is central to the objectives of InterTradeIreland (one of the Cross-border Bodies established as part of the Good Friday Agreement). Tables 7 and 8 therefore report Tobit models of 
export propensity for small plants (i.e. those with less than 50 employees) and larger plants respectively ${ }^{17}$.

In both cases Wald tests indicate that there is no significant difference between the internal resource effects of Northern Ireland and Irish plants. In common with the models discussed earlier, both small and larger businesses with higher skill levels tend to have higher export propensity ceteris paribus. Intriguing differences are observed, however, in the relationship between $R \& D$ and export competitiveness for the two groups of plants. For small plants, both informal and more formally organised inhouse R\&D activity have positive benefits for export propensity; for larger plants only formalised R\&D activity has any significant effect, and then only in Northern Ireland. The suggestion is that, for small plants at least, even informal R\&D can have significant commercial benefits in terms of increasing exports. In policy terms this result is important in that there may be an unwillingness to support informal $R \& D$ activity in small firms where this cannot be clearly identified by firms' accounting systems. This result also suggests the potential importance of informal R\&D activity to our understanding of the competitiveness of small firms. This is important because innovation surveys, in particular, have a well documented tendency to under-estimate the true level of any R\&D and developmental activity conducted informally (e.g. Kleinknecht, 1987; Kleinknecht, 1989; Kleinknecht et al., 1991). The importance of group R\&D for small Northern Ireland plants probably reflects the fact that many are parts of UK groups of companies, which is not the case in Ireland.

Other differences between the determinants of export propensity of small and larger plants largely reflect those already identified. For example, externally-owned plants in both plant sizebands have higher export propensity than indigenously-owned businesses in Ireland, but this is true only of larger plants in Northern Ireland. The age effect is again evident in Irish plants: the consistency of this effect suggests that this is a population effect among Irish plants. By contrast, the positive effect of age on export performance in Northern Ireland is restricted to large plants

\footnotetext{
${ }^{17} \mathrm{~A}$ Wald test for the equality of coefficients between large and small firms in the whole sample Tobit model is $\chi^{2}(19)=87.29(\rho<0.000)$;
} 


\section{Conclusions}

Our analysis of the determinants of manufacturing plants' export propensity in Northern Ireland and Ireland suggests three results applicable to all business types. First, plants with more highly skilled workforces - particularly more graduate employees - tend to be more successful in export markets. This is consistent with the findings of Braunerhjelm (1996) that investment in skilled labour improves export performance. Secondly, we find that larger plants tend to export a larger proportion of their sales. In common with other national studies, however, the increase in export propensity is less than proportionate to plant size (Wagner, 1995; Bernard and Wagner, 1997; Wakelin, 1998a; Bernard and Jensen, 1999; Sterlacchini, 1999; Bleaney and Wakelin, 2002). Thirdly, externally-owned plants export a larger proportion of their output than similar indigenously-owned plants, in part reflecting the findings of previous research that being part of a multi-plant group provides access to a deeper resource base (Roper and Love, 2002). The impact of other influences on plants' export propensity depends strongly on the plants' location, its size and its ownership. Older plants, for example, tend to export more in Northern Ireland (at least among larger plants) but have lower export propensity in Ireland. The latter effect is apparent among large, small, indigenous and externally-owned plants. External ownership is also much more strongly linked to increased export propensity in the Ireland than in Northern Ireland.

Important differences are also evident between groups of plants in terms of their sources of new technology and in particular the impact of R\&D on export propensity. For indigenously-owned plants, in-house R\&D - both inside and outside a formal R\&D department - is significant. For externally-owned plants in Northern Ireland (but not in Ireland), R\&D conducted elsewhere in the group proves more important. These empirical results are important from two standpoints. First, from a policy point of view they emphasise the importance of R\&D and associated developments to export competitiveness and growth. Secondly, in terms of the differences between small and larger plants, they emphasise contrasts between the different types of R\&D activity which influence export propensity. Small plants' export propensity, for example, is positively influenced by both informal and formally organised $R \& D$ activity; for larger plants, however, only more formally organised R\&D is helpful. 
These findings represent an advance on previous research which has regarded R\&D and the technological level of firms' capital stock in a relatively undifferentiated way (Wakelin, 1998a; Sterlacchini, 1999; Bleaney and Wakelin, 2002).

To illustrate the implications for export propensity of these differences, and the differential characteristics of plants in Northern Ireland and Ireland, Figure 2 gives predicted export propensities for plants of different sizes in each area. As we would expect, export propensity in both areas increases with employment, with significantly stronger scale effects in Northern Ireland than in Ireland. More interestingly, however, the Tobit models suggest that on average export propensity in Northern Ireland is around 13 pp below that in Ireland for plants with around 100 employees, a deficit which falls to virtually nil for plants with $600-700$ people. Given the differences in export growth in the two areas it is also interesting to explore whether differences in export propensity are structural or behavioural in nature, i.e. whether they can explained by differences in sectoral structure/ownership etc. To this end, Figure 3 reproduces the predicted export propensity of Northern Ireland and Ireland plants from Figure 2 and includes an additional series based on the estimated export propensity model for Northern Ireland (Table 4) and plant characteristics in Ireland. The difference between this structurally adjusted line and that for Northern Ireland is the structural effect. The difference between the structurally adjusted line and that for Ireland is due to differences in the behavioural relationship which determines export propensity in the two areas.

This decomposition implies very different results for smaller and larger plants. For small plants in Northern Ireland, predicted export propensity is around $13 \mathrm{pp}$ lower than that in Ireland, of which around two thirds is behavioural and one third structural. In other words around one third of the predicted difference in the export propensity of small plants can be explained by industrial structure. The remaining shortfall (around $9 \mathrm{pp}$ ) is due to differences in the way plants in Northern Ireland and the Ireland approach export sales. For larger plants the story is radically different. By the time a plant in Northern Ireland reaches 450 employees, the difference in export propensity between it and its Irish equivalent is due almost entirely to differences in the industrial structure of the two areas. 
In policy terms, this study emphasises again the positive relationship between an aspect of business performance (i.e. export propensity), workforce quality and research and development. It also highlights lower than expected export propensity on the part of small plants in Northern Ireland, an issue which presents significant policy challenges for the future. 
Figure 1: Real Exports Growth in Northern Ireland and Ireland Since 1991

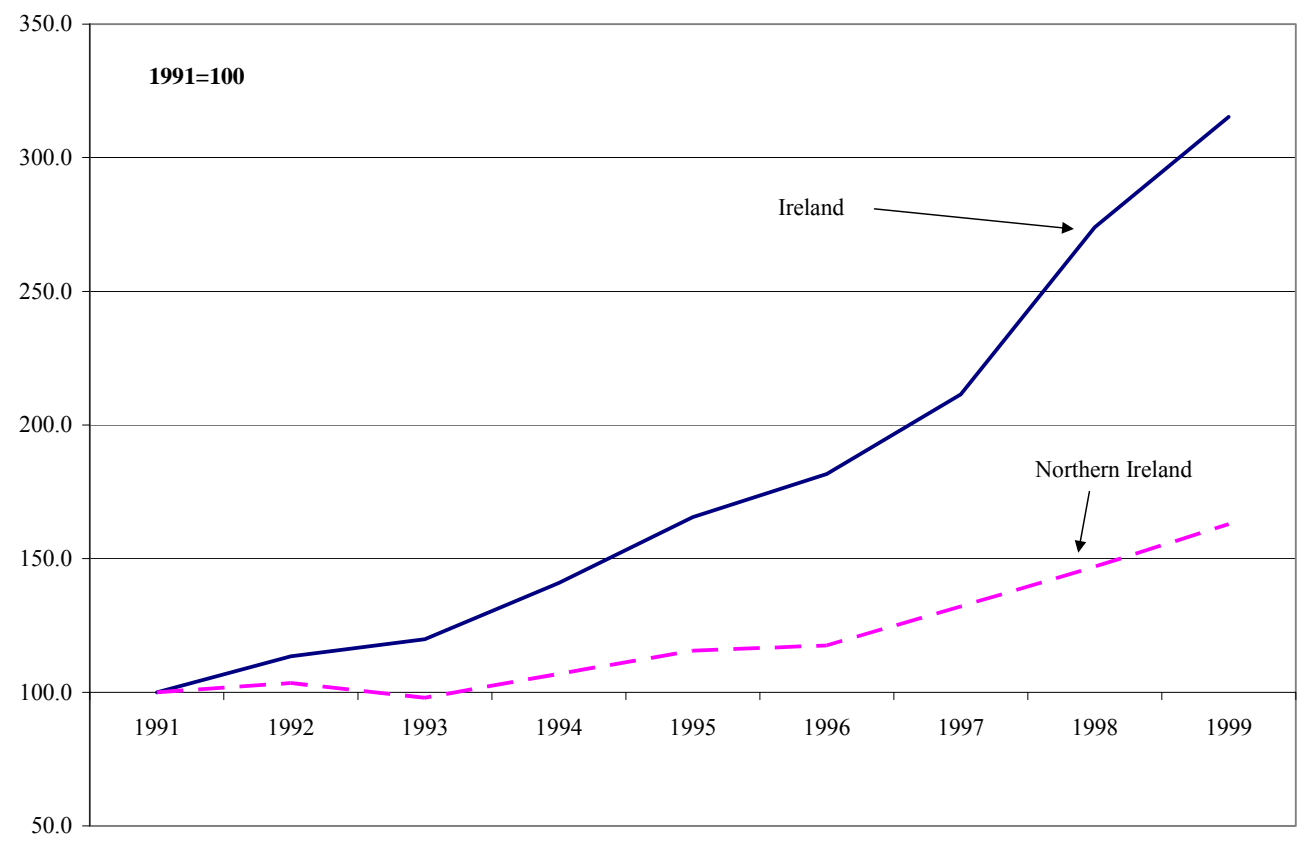

Sources: See Annex 


\section{Figure 2: Predicted Export Propensity By Plant Size: Northern Ireland and}

\section{Ireland}

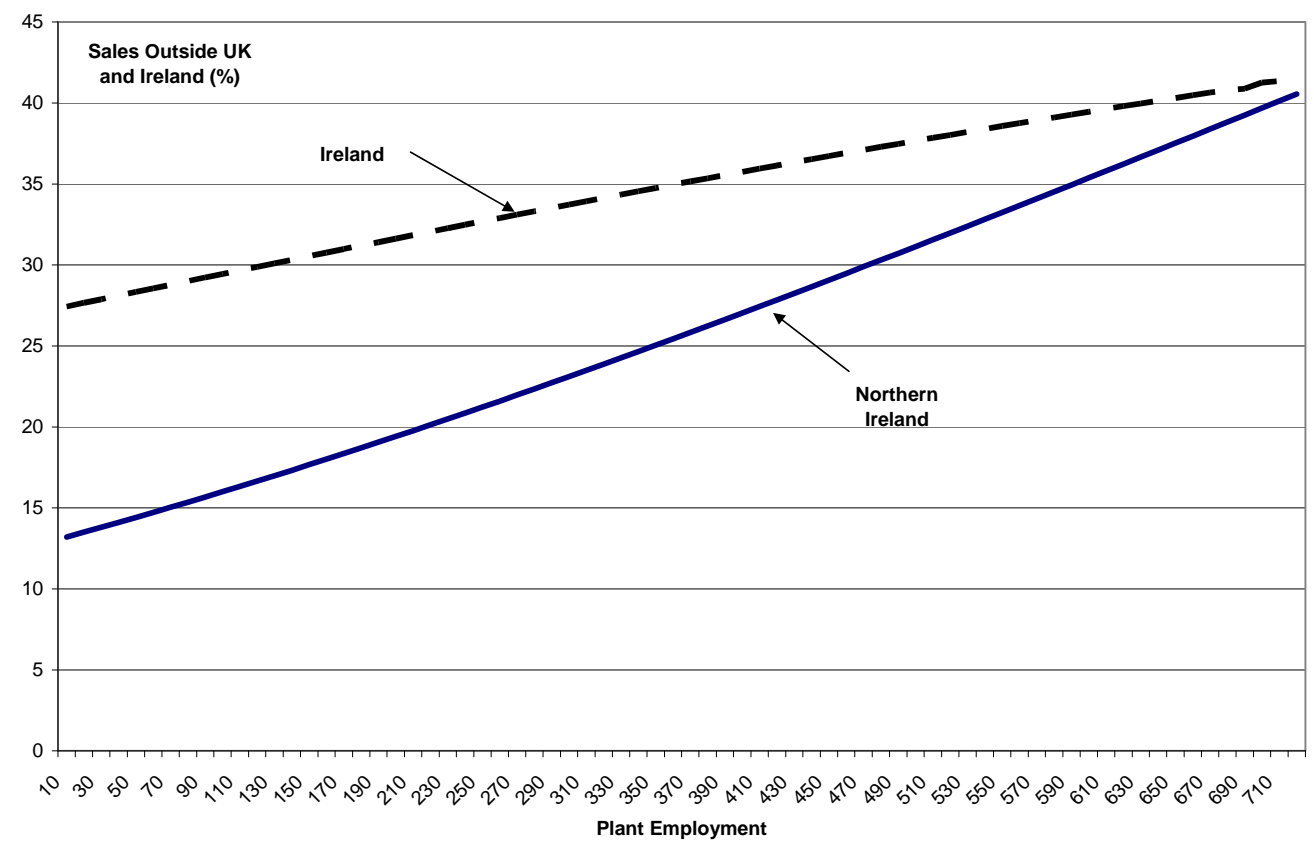

Notes: Predicted values relate to sales outside the UK and Ireland only, and were constructed using estimated parameters in Table 4. Predicted values were estimated using the method outlined in the text. Variable values are set to the mean for Northern Ireland and Ireland.

Source: Irish Innovation Panel, Table 4. 
Figure 3: Predicted and Structurally Adjusted Export Propensity By Area

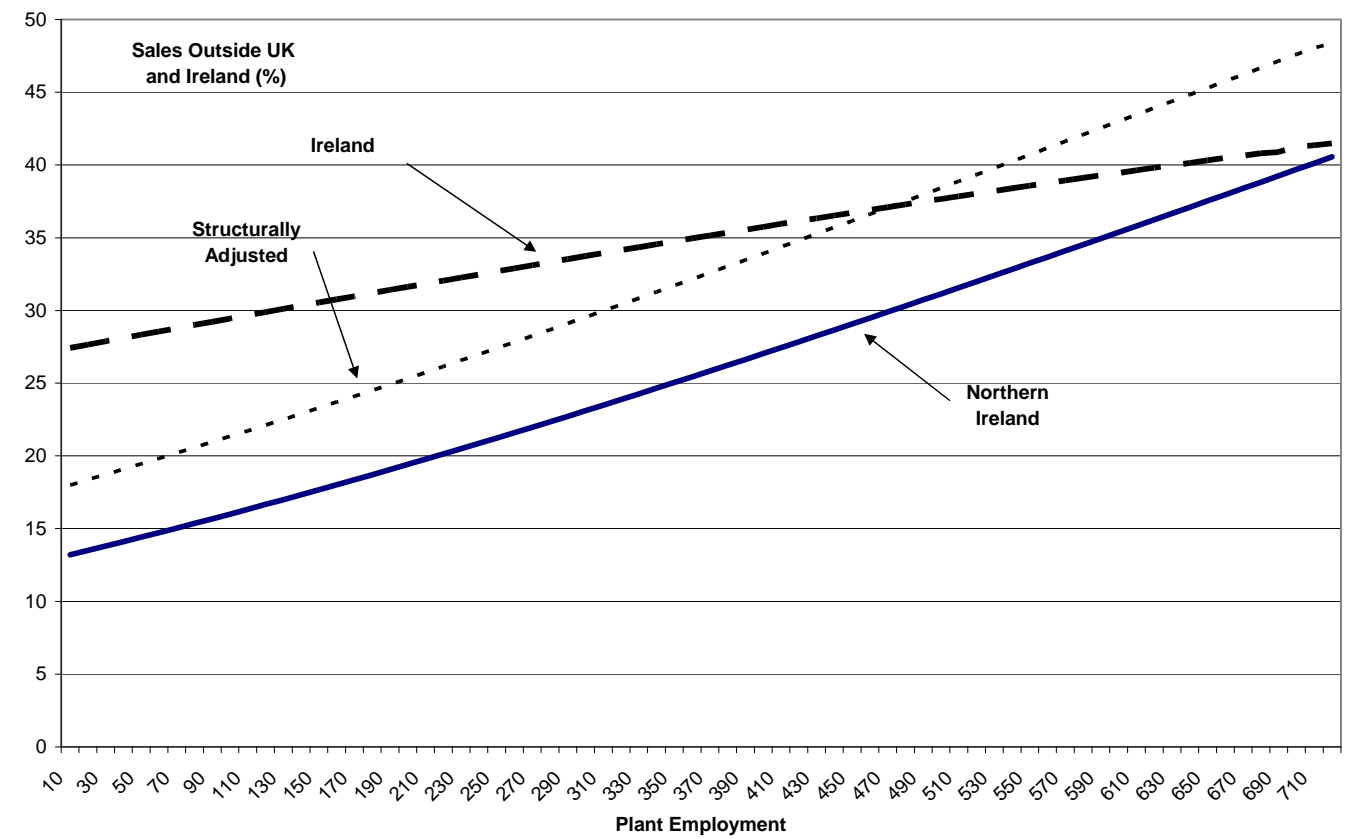

Notes: Predicted values relate to sales outside the UK and Ireland only, and were constructed using estimated parameters in Table 4. Predicted values were estimated using the method outlined in the text. Variable values are set to the mean for Northern Ireland and the Ireland.

Source: Irish Innovation Panel, Table 4. 
Table 1: Manufacturing Export Growth and Composition: 1991-99

1991

1993

1995

1997

1999

\section{A. Ireland (\%)}

Food, Drink and Tobacco

Textiles, Clothing and Leather

Chemicals \& Man-made Fibres

Basic Metals \& Fabricated Metal Products

and other Machinery and Equipment

Electrical \& Optical Equip.

Transport Equipment

Other Manufacturing inc. $\mathrm{R} \& \mathrm{P}$

and Coke and Petroleum Products

Total Manufacturing (\%)

Total Manufacturing EIRm 1995

\begin{tabular}{rrrrr}
25.3 & 25.6 & 22.6 & 13.8 & 10.4 \\
6.9 & 5.4 & 4.4 & 3.4 & 2.0 \\
19.5 & 22.2 & 21.7 & 29.2 & 35.8 \\
10.0 & 7.2 & 6.6 & 6.1 & 4.3 \\
& & & & \\
31.5 & 34.1 & 40.0 & 43.2 & 43.9 \\
1.4 & 1.0 & 0.9 & 1.1 & 1.2 \\
5.6 & 4.5 & 3.7 & 3.2 & 2.4 \\
& & & & \\
100.0 & 100.0 & 100.0 & 100.0 & 100.0 \\
$\mathbf{1 4 0 1 2}$ & $\mathbf{1 6 7 8 2}$ & $\mathbf{2 3 1 9 9}$ & $\mathbf{2 9 6 1 9}$ & $\mathbf{4 4 1 7 7}$ \\
\hline
\end{tabular}

\section{B. Northern Ireland}

Food, Drink \& Tobacco

Textiles, Clothing \& Leather

$\begin{array}{rrrrr}30.7 & 29.3 & 26.9 & 25.1 & 26.3 \\ 17.2 & 17.9 & 17.1 & 16.3 & 11.5 \\ 9.0 & 8.3 & 8.1 & 6.9 & 5.3 \\ 7.9 & 11.4 & 11.5 & 10.5 & 9.4 \\ & & & & \\ 8.1 & 9.5 & 11.2 & 13.3 & 17.6 \\ 14.8 & 11.3 & 11.6 & 14.5 & 16.4 \\ 12.2 & 12.5 & 13.6 & 13.4 & 13.5\end{array}$

Chemicals \& Man-made Fibres

Basic Metals \& Fabricated Metal Products and

other Machinery and Equipment

Electrical \& Optical Equip.

Transport Equipment

Other Manufacturing inc. $\mathrm{R} \& \mathrm{P}$ and

$100.0 \quad 100.0$

Total Manufacturing (\%)

\begin{tabular}{lllll}
5039 & 4936 & 5824 & 6652 & 8207 \\
\hline
\end{tabular}

\section{Notes and Sources: See Annex 1.}


Table 2: Structure of Irish Innovation Panel

\begin{tabular}{|c|c|c|c|c|c|c|}
\hline \multirow[t]{2}{*}{ Surveys } & \multicolumn{2}{|c|}{$\begin{array}{l}\text { Northern } \\
\text { Ireland }\end{array}$} & \multicolumn{2}{|c|}{ Ireland } & \multicolumn{2}{|c|}{$\begin{array}{c}\text { All } \\
\text { Plants }\end{array}$} \\
\hline & Plants & $\begin{array}{c}\text { Obser- } \\
\text { vations }\end{array}$ & Plants & $\begin{array}{l}\text { Obser- } \\
\text { vations }\end{array}$ & Plants & $\begin{array}{l}\text { Obser- } \\
\text { vations }\end{array}$ \\
\hline $2^{\text {nd }}$ and $3^{\text {rd }}$ & 146 & 403 & 198 & 549 & 344 & 952 \\
\hline $2^{\text {nd }}$ only & 147 & 252 & 261 & 436 & 408 & 688 \\
\hline $3^{\text {rd }}$ only & 273 & 273 & 438 & 438 & 711 & 711 \\
\hline Total & 566 & 928 & 897 & 1423 & 1463 & 2351 \\
\hline
\end{tabular}

Source: Irish Innovation Panel 
Table 3: Descriptive Data

\begin{tabular}{|c|c|c|c|c|}
\hline \multirow[b]{3}{*}{ Number of Observations } & \multicolumn{2}{|c|}{ Ireland } & \multicolumn{2}{|c|}{$\begin{array}{l}\text { Northern } \\
\text { Ireland }\end{array}$} \\
\hline & 1996 & 1999 & 1996 & 1999 \\
\hline & 459 & 636 & 293 & 419 \\
\hline Export Propensity (\% sales) & 35.3 & 30.7 & 15.5 & 17.8 \\
\hline \multicolumn{5}{|l|}{ Internal Resource Indicators } \\
\hline Workforce with degree (mean \%) & 9.2 & 9.2 & 6.6 & 7.4 \\
\hline Informal R\&D Only (\% plants) & 26.6 & 27.5 & 28.0 & 27.7 \\
\hline R\&D Dept In Plant (\% plants) & 25.5 & 26.6 & 17.0 & 18.5 \\
\hline R\&D Elsewhere In Group (\% plants) & 37.8 & 29.7 & 18.5 & 19.0 \\
\hline Plant Size (Employment) & 153.6 & 114.6 & 124.4 & 113.5 \\
\hline \multicolumn{5}{|l|}{ Other Plant Characteristics } \\
\hline Age Of Plant (Years) & 27.5 & 25.6 & 36.5 & 31.5 \\
\hline Externally-Owned (\% plants) & 40.6 & 29.8 & 10.7 & 13.2 \\
\hline Small Batch Production (\% plants) & 43.7 & 39.3 & 48.1 & 40.7 \\
\hline Large Batch Production (\% plants) & 38.7 & 26.9 & 32.0 & 29.0 \\
\hline \multicolumn{5}{|l|}{ Industry Indicators (\% plants) } \\
\hline Food, Drink & 19.4 & 16.2 & 18.1 & 17.9 \\
\hline Textiles, Clothing & 9.2 & 8.0 & 16.7 & 15.5 \\
\hline Wood and Wood Prods & 5.5 & 3.6 & 7.9 & 5.0 \\
\hline Paper and Printing & 7.4 & 6.3 & 6.5 & 7.2 \\
\hline Chemicals etc & 10.2 & 8.0 & 4.1 & 3.3 \\
\hline Metals, Fabrication & 9.4 & 11.5 & 6.8 & 10.3 \\
\hline Mechanical Engineering & 5.7 & 8.0 & 10.9 & 6.7 \\
\hline Electronics, Optical & 18.3 & 16.4 & 5.5 & 7.2 \\
\hline Transport Equipment & 3.7 & 2.8 & 3.4 & 4.3 \\
\hline Other Manufacturing & 11.3 & 19.2 & 20.1 & 22.7 \\
\hline
\end{tabular}

Note: Export propensity relates to sales outside the UK and Ireland.

Source: Irish Innovation Panel 
Table 4: Tobit Models of the Export Propensity of Manufacturing Plants

\begin{tabular}{|c|c|c|c|c|c|c|}
\hline & \multicolumn{2}{|c|}{ Combined Sample } & \multicolumn{2}{|c|}{ Northern Ireland } & \multicolumn{2}{|c|}{ Ireland } \\
\hline & Coeff & t-ratio & Coeff & t-ratio & Coeff & t-ratio \\
\hline Constant & -18.386 & -4.675 & -29.535 & -5.307 & -15.127 & -3.102 \\
\hline \multicolumn{7}{|l|}{ Internal Resource Indicators } \\
\hline Workforce With Degree (\%) & 0.477 & 4.091 & 0.886 & 4.155 & 0.34 & 2.528 \\
\hline Informal R\&D Only & 10.571 & 3.784 & 17.409 & 3.94 & 8.192 & 2.363 \\
\hline R\&D Dept In Plant & 17.97 & 5.77 & 22.324 & 4.032 & 14.174 & 3.88 \\
\hline R\&D Elsewhere In Group & 5.033 & 1.524 & 6.29 & 1.13 & 3.933 & 0.98 \\
\hline Plant Size (Employment) & 0.025 & 3.092 & 0.063 & 3.389 & 0.033 & 2.823 \\
\hline Plant Size (Empl) Sqrd. & -0.034 & -1.847 & -0.084 & -2.652 & -0.094 & -2.321 \\
\hline \multicolumn{7}{|l|}{ Other Plant Characteristics } \\
\hline Age Of Plant (Years) & -0.059 & -1.42 & 0.09 & 1.657 & -0.232 & -3.812 \\
\hline Externally-Owned & 32.647 & 9.353 & 11.321 & 1.817 & 37.986 & 9.161 \\
\hline Small Batch Production & 2.24 & 0.919 & -0.27 & -0.069 & 2.747 & 0.919 \\
\hline Large Batch Production & 6.214 & 2.422 & -1.006 & -0.234 & 8.646 & 2.803 \\
\hline Northern Ireland Plant & -7.14 & -2.787 & & & & \\
\hline \multicolumn{7}{|l|}{ Industry Dummies } \\
\hline Food, Drink & 2.663 & 0.646 & -9.056 & -1.401 & 10.868 & 2.101 \\
\hline Textiles, Clothing & 21.445 & 4.821 & 11.075 & 1.751 & 27.49 & 4.64 \\
\hline Wood and Wood Prods & -8.267 & -1.267 & -8.435 & -0.905 & -9.041 & -1.059 \\
\hline Paper and Printing & -8.584 & -1.406 & 2.664 & 0.296 & -12.779 & -1.63 \\
\hline Chemicals etc & 30.411 & 5.63 & 3.994 & 0.379 & 35.282 & 5.658 \\
\hline Metals, Fabrication & 5.334 & 1.125 & 21.903 & 2.97 & -3.02 & -0.512 \\
\hline Mechanical Engineering & 17.612 & 3.497 & 17.334 & 2.302 & 15.956 & 2.498 \\
\hline Electronics, Optical & 25.719 & 5.789 & 24.791 & 3.014 & 24.767 & 4.74 \\
\hline Transport Equipment & 18.894 & 2.834 & 3.984 & 0.37 & 22.984 & 2.788 \\
\hline Sigma & 38.948 & 37.14 & 36.781 & 21.068 & 37.902 & 30.686 \\
\hline Log-L & -4382.56 & & -1439.06 & & -2904.5 & \\
\hline $\mathrm{N}$ & 1327 & & 490 & & 837 & \\
\hline Pseudo R² (Anova) & 0.138 & & 0.223 & & 0.175 & \\
\hline Pseudo R² (Decomp) & 0.149 & & 0.15 & & 0.211 & \\
\hline LR test & $3439.77(\mathrm{p}$ & $0.000)$ & $1257.69(\mathrm{p}$ & $.000)$ & $2168.34(\mathrm{p}$ & $.000)$ \\
\hline
\end{tabular}

Notes

1. Equations are standard Tobit models. The omitted industry dummy variable relates to Other Manufacturing nes. LR test compares the estimated equation to a model including only a constant term.

2. In the combined sample model, Wald tests for the equality of coefficients for the 1994-96 and 1997-99 periods were as follows: all coefficients, $\chi^{2}(20)=17.23(\rho=0.637)$; internal resource indicators, $\chi^{2}(6)=9.23(\rho=0.161)$; other plant characteristics, $\chi^{2}(4)=3.18(\rho=0.529)$; Northern Ireland dummy variable, $\chi^{2}(1)=0.59(\rho=0.444)$; industry effects, $\chi^{2}(9)=6.14$ $(\rho=0.725)$. In each case the hypothesis of equality cannot be rejected. Wald tests for the equality of coefficients for Northern Ireland and Ireland (omitting the Northern Ireland dummy) were as follows: all coefficients, $\chi^{2}(19)=81.37(\rho<0.000)$; internal resource indicators, $\chi^{2}(6)=15.88(\rho=0.014)$; other plant characteristics, $\chi^{2}(4)=30.02(\rho<0.000)$; industry effects, $\chi^{2}(9)=36.14(\rho<0.000)$. For each group of coefficients the hypothesis of equality is rejected. 
3. Wald tests for the equality of coefficients for the 1994-96 and 1997-99 periods for Northern Ireland were as follows: all coefficients, $\chi^{2}(20)=13.28(\rho=0.823)$; internal resource indicators, $\chi^{2}(6)=4.23(\rho=0.645)$; other plant characteristics, $\chi^{2}(4)=4.57(\rho=0.334)$; industry effects, $\chi^{2}(9)=5.00(\rho=0.834)$. In each case the hypothesis of equality cannot be rejected. Models estimated separately for the two periods are available on request.

4. Wald tests for the equality of coefficients for the 1994-96 and 1997-99 periods for Ireland were as follows: all coefficients, $\chi^{2}(20)=18.29(\rho=0.503)$; internal resource indicators, $\chi^{2}(6)$ $=5.23(\rho=0.514)$; other plant characteristics, $\chi^{2}(4)=5.87(\rho=0.209)$; industry effects, $\chi^{2}(9)=$ $9.01(\rho=0.436)$. In each case the hypothesis of equality cannot be rejected.

Source: Irish Innovation Panel 
Table 5: Tobit Models of Export Propensity of Indigenously -Owned Plants

\begin{tabular}{|c|c|c|c|c|c|c|}
\hline & \multicolumn{2}{|c|}{ Combined Sample } & \multicolumn{2}{|c|}{ Northern Ireland } & \multicolumn{2}{|c|}{ Ireland } \\
\hline & Coeff & t-ratio & Coeff & t-ratio & Coeff & t-ratio \\
\hline Constant & -26.556 & -5.823 & -32.103 & -5.380 & -25.044 & -4.037 \\
\hline \multicolumn{7}{|c|}{ Internal Resource Indicators } \\
\hline$\%$ With Degree $(\%)$ & 0.581 & 3.945 & 1.027 & 4.773 & 0.264 & 1.355 \\
\hline Informal R\&D Only & 14.037 & 4.43 & 17.223 & 3.893 & 12.995 & 3.028 \\
\hline R\&D Dept In Plant & 22.739 & 5.865 & 23.820 & 4.161 & 19.437 & 3.883 \\
\hline R\&D In Group & -6.873 & -1.569 & -3.756 & -0.612 & -5.431 & -0.901 \\
\hline Plant Size (Empl) & 0.153 & 4.878 & 0.217 & 3.100 & 0.195 & 4.757 \\
\hline Plant Size (Empl) Sqrd. & -1.65 & -3.073 & -5.033 & -2.679 & -1.956 & -3.153 \\
\hline \multicolumn{7}{|c|}{ Other Plant Characteristics } \\
\hline Age Of Plant (Years) & -0.039 & -0.862 & 0.087 & 1.648 & -0.174 & -2.308 \\
\hline Small Batch Production & 2.707 & 0.96 & 2.386 & 0.605 & 4.148 & 1.085 \\
\hline Large Batch Production & 3.233 & 1.062 & -5.200 & -1.176 & 8.092 & 1.992 \\
\hline N. Ireland Plant & -2.69 & -0.961 & & & & \\
\hline \multicolumn{7}{|l|}{ Industry Dummies } \\
\hline Food, Drink & 5.848 & 1.302 & -7.432 & -1.149 & 12.120 & 2.018 \\
\hline Textiles, Clothing & 20.041 & 4.207 & 12.969 & 2.030 & 27.942 & 4.205 \\
\hline Wood and Wood Prods & -4.324 & -0.627 & -6.351 & -0.711 & -5.222 & -0.535 \\
\hline Paper and Printing & -6.079 & -0.966 & 2.040 & 0.238 & -11.400 & -1.328 \\
\hline Chemicals etc & 24.12 & 3.148 & 13.818 & 1.245 & 28.861 & 2.870 \\
\hline Metals, Fabrication & 2.261 & 0.437 & 16.246 & 2.250 & -8.482 & -1.218 \\
\hline Mech Engineering & 10.066 & 1.823 & 11.975 & 1.648 & 4.172 & 0.539 \\
\hline Electronics, Optical & 15.139 & 2.527 & 9.321 & 0.954 & 16.492 & 2.230 \\
\hline Transport Equipment & 11.784 & 1.426 & -1.747 & -0.150 & 19.795 & 1.794 \\
\hline Sigma & 37.377 & 29.402 & 34.167 & 19.098 & 37.151 & 22.490 \\
\hline Log-L & -2819.76 & & -1179.640 & & -1611.350 & \\
\hline $\mathrm{N}$ & 961 & & 422.000 & & 539.000 & \\
\hline Pseudo R ${ }^{2}$ (Anova) & 0.103 & & 0.143 & & 0.141 & \\
\hline Pseudo R ${ }^{2}$ (Decomp) & 0.076 & & 0.107 & & 0.090 & \\
\hline LR test & $1410.00(\mathrm{p}$ & $=0.000)$ & $687.84(0$. & & $771.87(0.0$ & \\
\hline
\end{tabular}

\section{Notes}

1. Equations are standard Tobit models. The omitted industry dummy variable relates to Other Manufacturing nes. LR test compares the estimated equation to a model including only a constant term.

2. Wald tests for the equality of coefficients for the 1994-96 and 1997-99 periods for indigenously-owned plants were as follows: all coefficients, $\chi^{2}(20)=19.56(\rho=0.421)$; internal resource indicators, $\chi^{2}(6)=5.06(\rho=0.536)$; other plant characteristics, $\chi^{2}(4)=1.62$ $(\rho=0.655)$; Northern Ireland dummy, $\chi^{2}(1)=1.74(\rho=0.187)$; industry effects, $\chi^{2}(9)=12.36$ $(\rho=0.193)$. In each case the hypothesis of equality cannot be rejected. Models estimated separately for the two periods are available on request.

3. Wald tests for the equality of coefficients for Northern Ireland and Ireland were as follows (omitting the Northern Ireland dummy variable): all coefficients, $\chi^{2}(18)=52.95(\rho=0.000)$; internal resource indicators, $\chi^{2}(6)=11.15(\rho=0.083)$; other plant characteristics, $\chi^{2}(3)=$ $10.39(\rho=0.015)$; industry effects, $\chi^{2}(9)=29.78(\rho=0.000)$. In each case the hypothesis of equality cannot be rejected at the 10 per cent level.

Source: Irish Innovation Panel 
Table 6: Tobit Models of Export Propensity of Externally-Owned Plants

\begin{tabular}{|c|c|c|c|c|c|c|}
\hline & \multicolumn{2}{|c|}{ Combined Sample } & \multicolumn{2}{|c|}{ Northern Ireland } & \multicolumn{2}{|c|}{ Ireland } \\
\hline & Coeff & t-ratio & Coeff & t-ratio & Coeff & t-ratio \\
\hline Constant & 17.615 & 2.283 & -31.823 & -1.920 & 23.169 & 2.847 \\
\hline \multicolumn{7}{|c|}{ Internal Resource Indicators } \\
\hline \% With Degree (\%) & 0.4269 & 2.39 & -0.278 & -0.397 & 0.506 & 2.836 \\
\hline Informal R\&D Only & 4.439 & 0.83 & 23.104 & 1.810 & 3.164 & 0.553 \\
\hline R\&D Dept In Plant & 4.56 & 0.915 & 24.294 & 1.749 & 1.907 & 0.369 \\
\hline R\&D In Group & 12.635 & 2.57 & 45.585 & 3.947 & 7.660 & 1.439 \\
\hline Plant Size (Empl) & 0.015 & 1.68 & 0.030 & 1.222 & 0.019 & 1.502 \\
\hline Plant Size (Empl) Sqrd. & -0.006 & -0.351 & -0.030 & -0.792 & -0.045 & -1.049 \\
\hline \multicolumn{7}{|c|}{ Other Plant Characteristics } \\
\hline Age Of Plant (Years) & -0.167 & -1.79 & 0.309 & 1.385 & -0.276 & -2.774 \\
\hline Small Batch Production & 3.653 & 0.832 & -21.154 & -1.890 & 4.272 & 0.927 \\
\hline Large Batch Production & 9.809 & 2.259 & -2.273 & -0.197 & 10.831 & 2.413 \\
\hline N. Ireland Plant & -19.582 & -3.569 & & & & \\
\hline \multicolumn{7}{|l|}{ Industry Dummies } \\
\hline Food, Drink & -8.48 & -0.959 & -20.752 & -1.126 & -6.527 & -0.678 \\
\hline Textiles, Clothing & 9.501 & 0.897 & 0.664 & 0.037 & 13.733 & 1.112 \\
\hline Wood and Wood Prods & -14.736 & -0.948 & -195.543 & -0.027 & -9.188 & -0.568 \\
\hline Paper and Printing & -22.588 & -1.225 & -188.218 & -0.018 & -17.572 & -0.931 \\
\hline Chemicals etc & 31.386 & 3.881 & -48.119 & -1.749 & 35.987 & 4.265 \\
\hline Metals, Fabrication & 20.192 & 2.005 & 58.148 & 2.557 & 15.143 & 1.441 \\
\hline Mech Engineering & 40.948 & 3.921 & 97.209 & 3.408 & 38.809 & 3.604 \\
\hline Electronics, Optical & 30.381 & 4.339 & 53.527 & 3.525 & 28.585 & 3.804 \\
\hline Transport Equipment & 28.199 & 2.642 & 10.171 & 0.469 & 26.660 & 2.277 \\
\hline Sigma & 37.322 & 22.782 & 32.774 & 9.099 & 35.419 & 20.996 \\
\hline Log-L & -1519.8 & & -233.155 & & -1261.03 & \\
\hline $\mathrm{N}$ & 366 & & 68 & & 298 & \\
\hline Pseudo R ${ }^{2}$ (Anova) & 0.295 & & 1.454 & & 0.385 & \\
\hline Pseudo $\mathrm{R}^{2}$ (Decomp) & 0.399 & & 0.375 & & 0.427 & \\
\hline LR test & $535.7(\mathrm{p}<0$. & & $132.2(0.000$ & & $428.39(0$. & \\
\hline
\end{tabular}

\section{Notes}

1. Equations are standard Tobit models. The omitted industry dummy variable relates to Other Manufacturing nes. LR test compares the estimated equation to a model including only a constant term.

2. Wald tests for the equality of coefficients for the 1994-96 and 1997-99 periods for externallyowned plants were as follows: all coefficients, $\chi^{2}(20)=19.56(\rho=0.421)$; internal resource indicators, $\chi^{2}(6)=5.06(\rho=0.536)$; other plant characteristics, $\chi^{2}(4)=1.62(\rho=0.655)$; Northern Ireland dummy, $\chi^{2}(1)=1.74(\rho=0.187)$; industry effects, $\chi^{2}(9)=12.36(\rho=0.193)$. In each case the hypothesis of equality cannot be rejected.

3. Wald tests for the equality of coefficients for Northern Ireland and Ireland were as follows: all coefficients, $\chi^{2}(18)=53.47(\rho=0.000)$; internal resource indicators, $\chi^{2}(6)=9.97(\rho=0.126)$; other plant characteristics, $\chi^{2}(4)=14.04(\rho=0.003)$; industry effects, $\chi^{2}(9)=22.58(\rho=0.007)$. Overall, the hypothesis of equality is rejected as it is for other plant characteristics and the industry effects.

Source: Irish Innovation Panel 
Table 7: Tobit Models of Export Propensity of Small Plants

\begin{tabular}{|c|c|c|c|c|c|c|}
\hline & \multicolumn{2}{|c|}{ Combined Sample } & \multicolumn{2}{|c|}{ Northern Ireland } & \multicolumn{2}{|c|}{ Ireland } \\
\hline & Coeff & t-ratio & Coeff & t-ratio & Coeff & t-ratio \\
\hline Constant & -51.902 & -4.667 & -32.474 & -2.224 & -60.833 & -3.875 \\
\hline \multicolumn{7}{|c|}{ Internal Resource Indicators } \\
\hline \% With Degree (\%) & 0.566 & 3.279 & 0.894 & 3.473 & 0.376 & 1.689 \\
\hline Informal R\&D Only & 13.842 & 3.415 & 18.558 & 3.209 & 12.210 & 2.272 \\
\hline R\&D Dept In Plant & 18.969 & 3.336 & 20.632 & 2.236 & 17.257 & 2.465 \\
\hline R\&D Elsewhere In Group & 8.75 & 1.422 & 20.362 & 1.981 & 1.294 & 0.172 \\
\hline Plant Size (Empl). & 1.692 & 2.256 & 0.097 & 0.090 & 2.569 & 2.457 \\
\hline Plant Size (Empl) Sqrd & -169.307 & -1.354 & 86.106 & 0.446 & -314.881 & -1.874 \\
\hline \multicolumn{7}{|c|}{ Other Plant Characteristics } \\
\hline Age Of Plant (Years) & -0.165 & -2.17 & -0.060 & -0.594 & -0.201 & -1.931 \\
\hline Externally-Owned & 36.654 & 5.405 & -0.339 & -0.027 & 49.617 & 6.061 \\
\hline Small Batch Production & 2.231 & 0.61 & 0.947 & 0.176 & -0.103 & -0.021 \\
\hline Large Batch Production & 0.499 & 0.117 & -10.405 & -1.636 & 6.623 & 1.212 \\
\hline N. Ireland Plant & -1.23 & -0.327 & & & & \\
\hline \multicolumn{7}{|l|}{ Industry Dummies } \\
\hline Food, Drink & -0.393 & -0.064 & -7.809 & -0.898 & 4.776 & 0.594 \\
\hline Textiles, Clothing & 20.336 & 3.143 & 14.835 & 1.644 & 24.698 & 2.869 \\
\hline Wood and Wood Prods & -8.767 & -1.024 & -8.230 & -0.723 & -8.597 & -0.734 \\
\hline Paper and Printing & -6.669 & -0.793 & 3.824 & 0.328 & -11.361 & -1.003 \\
\hline Chemicals etc & 7.833 & 0.843 & -13.730 & -0.826 & 16.318 & 1.445 \\
\hline Metals, Fabrication & -0.198 & -0.032 & 15.768 & 1.786 & -12.348 & -1.479 \\
\hline Mech Engineering & 9.887 & 1.448 & 14.504 & 1.569 & 2.766 & 0.292 \\
\hline Electronics, Optical & 20.016 & 2.655 & 14.602 & 1.035 & 21.265 & 2.405 \\
\hline Transport Equipment & 1.323 & 0.122 & -7.958 & -0.520 & 10.523 & 0.726 \\
\hline Sigma & & & 35.424 & 14.001 & 40.627 & 18.280 \\
\hline Log-L & -1836.28 & & -672.945 & & -1142.920 & \\
\hline $\mathrm{N}$ & 696 & & 277.000 & & 419.000 & \\
\hline Pseudo R ${ }^{2}$ (Anova) & 0.172 & & 0.236 & & 0.199 & \\
\hline Pseudo R ${ }^{2}$ (Decomp) & 0.147 & & 0.198 & & 0.143 & \\
\hline LR test & $1525.14(\mathrm{p}$ & $.000)$ & $644.9(0.000)$ & & $893.8(0.000)$ & \\
\hline
\end{tabular}

\section{Notes}

1. Equations are standard Tobit models. The omitted industry dummy variable relates to Other Manufacturing nes. LR test compares the estimated equation to a model including only a constant term.

2. Wald tests for the equality of coefficients for the 1994-96 and 1997-99 periods were as follows: all coefficients, $\chi^{2}(20)=13.24(\rho=0.866)$; internal resource indicators, $\chi^{2}(6)=4.02$ $(\rho=0.673)$; other plant characteristics, $\chi^{2}(4)=5,89(\rho=0.207)$; Northern Ireland dummy, $\chi^{2}(1)$ $=0.19(\rho=0.659)$; industry effects, $\chi^{2}(9)=4.56(\rho=0.870)$. In each case the hypothesis of equality cannot be rejected.

3. Wald tests for the equality of coefficients for Northern Ireland and Ireland were as follows: all coefficients, $\chi^{2}(19)=36.26(\rho=0.009)$; internal resource indicators, $\chi^{2}(6)=8.43(\rho=0.208)$; other plant characteristics, $\chi^{2}(4)=14.72(\rho=0.005)$; industry effects, $\chi^{2}(9)=16.10(\rho=0.064)$. With the exception of the internal resource indicators, the hypothesis of equality cannot be rejected.

Source: Irish Innovation Panel 
Table 8: Tobit Models of Export Propensity of Larger Plants

\begin{tabular}{|c|c|c|c|c|c|c|}
\hline & \multicolumn{2}{|c|}{ Combined Sample } & \multicolumn{2}{|c|}{ Northern Ireland } & \multicolumn{2}{|c|}{ Ireland } \\
\hline & Coeff & t-ratio & Coeff & t-ratio & Coeff & t-ratio \\
\hline Constant & -1.686 & -0.294 & -20.605 & -2.252 & 1.257 & 0.184 \\
\hline \% With Degree (\%) & 0.6 & 3.828 & 0.930 & 2.501 & 0.523 & 3.106 \\
\hline Informal R\&D Only & 1.308 & 0.34 & 10.976 & 1.604 & -2.509 & -0.548 \\
\hline R\&D Dept In Plant & 8.006 & 2.174 & 14.853 & 2.009 & 3.801 & 0.909 \\
\hline R\&D Elsewhere In Group & 1.696 & 0.452 & -1.423 & -0.214 & 4.927 & 1.100 \\
\hline Plant Size (Empl). & 0.008 & 1.019 & 0.040 & 1.961 & 0.013 & 1.074 \\
\hline Plant Size (Empl) Sqrd & -0.002 & -0.113 & -0.051 & -1.497 & -0.030 & -0.754 \\
\hline Age Of Plant (Years) & -0.03 & -0.631 & 0.138 & 2.143 & -0.258 & -3.594 \\
\hline Externally-Owned & 23.077 & 5.812 & 14.194 & 1.945 & 24.243 & 5.205 \\
\hline Small Batch Production & 5.52 & 1.723 & 0.753 & 0.130 & 7.908 & 2.102 \\
\hline Large Batch Production & 5.783 & 1.856 & 3.084 & 0.526 & 4.795 & 1.338 \\
\hline N. Ireland Plant & -12.576 & -3.671 & & & & \\
\hline \multicolumn{7}{|l|}{ Industry Dummies } \\
\hline Food, Drink & 2.912 & 0.523 & -8.817 & -0.951 & 13.434 & 1.969 \\
\hline Textiles, Clothing & 19.511 & 3.229 & 6.842 & 0.783 & 29.087 & 3.579 \\
\hline Wood and Wood Prods & -8.023 & -0.797 & -19.669 & -1.271 & -0.751 & -0.059 \\
\hline Paper and Printing & -14.471 & -1.652 & 2.310 & 0.168 & -22.748 & -2.066 \\
\hline Chemicals etc & 39.174 & 5.874 & 17.927 & 1.244 & 43.439 & 5.732 \\
\hline Metals, Fabrication & 9.931 & 1.354 & 24.635 & 1.887 & 8.447 & 0.979 \\
\hline Mech Engineering & 31.579 & 4.213 & 23.425 & 1.812 & 35.555 & 4.006 \\
\hline Electronics, Optical & 27.636 & 4.925 & 25.402 & 2.416 & 27.484 & 4.143 \\
\hline Transport Equipment & 30.695 & 3.638 & 13.774 & 0.895 & 34.120 & 3.412 \\
\hline Sigma & 35.781 & 29.374 & 35.749 & 15.757 & 33.891 & 24.848 \\
\hline Log-L & -2499.82 & & -754.586 & & -1722.520 & \\
\hline $\mathrm{N}$ & 631 & & 213.000 & & 418.000 & \\
\hline Pseudo R ${ }^{2}$ (Anova) & 0.182 & & 0.168 & & 0.270 & \\
\hline Pseudo R ${ }^{2}$ (Decomp) & 0.314 & & 0.195 & & 0.373 & \\
\hline LR test & $1786.8(\mathrm{p}<0$ & $00)$ & $583.8(0.000)$ & & $1189.2(0.0$ & \\
\hline
\end{tabular}

\section{Notes}

1. Equations are standard Tobit models. The omitted industry dummy variable relates to Other Manufacturing nes. LR test compares the estimated equation to a model including only a constant term.

2. Wald tests for the equality of coefficients for the 1994-96 and 1997-99 periods were as follows: all coefficients, $\chi^{2}(20)=15.81(\rho=0.728)$; internal resource indicators, $\chi^{2}(6)=4.56$ $(\rho=0.601)$; other plant characteristics, $\chi^{2}(4)=2.41(\rho=0.661)$; Northern Ireland dummy, $\chi^{2}(1)$ $=1.30(\rho=0.253)$; industry effects, $\chi^{2}(9)=9.12(\rho=0.426)$. In each case the hypothesis of equality cannot be rejected.

3. Wald tests for the equality of coefficients for Northern Ireland and Ireland were as follows: all coefficients, $\chi^{2}(19)=56.20(\rho<0.000)$; internal resource indicators, $\chi^{2}(6)=6.31(\rho=0.388)$; other plant characteristics, $\chi^{2}(4)=18.19(\rho=0.011)$; industry effects, $\chi^{2}(9)=22.95(\rho=0.006)$. With the exception of the external resource indicators, the hypothesis of equality cannot be rejected.

Source: Irish Innovation Panel 


\section{Annex: Northern Ireland and Ireland Exports Data}

For Ireland nominal exports data is available from 1991 is published in Trade Statistics, (CSO, Dublin) on the basis of the SITC (Rev 3). For Northern Ireland data based on the 2-digit SIC 1980 and sic 1992 have been published in 'Made in Northern Ireland Sold to the World' (various dates, NIERC, Belfast). A consistent time-series for all Northern Ireland manufacturing was published in Appendix 2 of the 1997/98 to 98/99 report. Consistent data for industrial groups was provided by Maureen O'Reilly and Catherine Glass (NIERC) ${ }^{18}$. The main issue in making any Northern IrelandIreland comparisons is matching SIC and SITC based series. (In addition, the Irish exports data is reported for calendar years whereas the Northern Ireland exports series relate to financial years). The approximate matches used are given in Table A1. The resulting nominal series are given in Table A2 with Northern Ireland data in £m. and Irish data in $£ I R m$. Nominal series were deflated using export price deflators taken from Table 1, Trade Statistics August 2000, CSO Dublin and Table 1.21 (series BQKR), Economic Trends Annual Supplement 2000, National Statistics. Real export series (in 1995 prices) are given in Table A3.

Table A1: Sectoral Definitions Using SIC and SITC Codes

\begin{tabular}{lcc}
\hline & Ireland & Northern Ireland \\
\hline & $\begin{array}{c}\text { SITC (Rev 3) } \\
\text { Codes }\end{array}$ & SIC 92 Codes \\
Food, Drink \& Tobacco & $01-12,29,41-43$ & $15-16$ \\
Textiles, Clothing \& Leather & $21,26,61,65$, & $17-19$ \\
& $82-85$ & 24 \\
Chemicals \& Man-made Fibres & $27,51-56,59$ & $27-29$ \\
Basic Metals \& Fabricated Metal Products & $28,67-9$, & \\
and Other Machinery \& Equipment & $71-74$ & $30-33$ \\
& & $34-35$ \\
Electrical \& Optical Equipment & $75-77,87,88$ & \\
Transport Equipment & 78,79 & 26 \\
Other Manufacturing (including Coke \& & $23,32-34,57,58,62$, & $23,25,36-37,20,21-22$, \\
Petroleum products n.e.s, Wood \& Wood & $24,63,81,25,64,66$ & \\
Products, Paper \& Printing, Other Non- & & \\
Metallic Mineral Products) & & \\
& & \\
\hline
\end{tabular}

\footnotetext{
${ }^{18}$ Note that in the Northern Ireland exports reports 'exports' are taken as sales outside the UK. Here we use the term 'exports' to refer to any sales outside Northern Ireland whether to GB or elsewhere. This is called 'external sales' in the Northern Ireland exports reports.
} 
Table A2: Nominal Export Series for Northern Ireland and the Ireland: 1991-99

\begin{tabular}{|c|c|c|c|c|c|c|c|c|c|}
\hline & 1991 & 1992 & 1993 & 1994 & 1995 & 1996 & 1997 & 1998 & 1999 \\
\hline \multicolumn{10}{|l|}{ A. Ireland Export Sales (£IR million) } \\
\hline Food, Drink and Tobacco & 3322 & 4000 & 4220 & 4638 & 5252 & 4612 & 4119 & 4449 & 4752 \\
\hline Textiles, Clothing and Leather & 906 & 938 & 889 & 1015 & 1027 & 1025 & 1016 & 1049 & 922 \\
\hline Chemicals \& Man-made Fibres & 2,565 & 3,086 & 3,662 & 4,631 & 5,038 & 6,575 & 8,705 & 14,081 & 16,362 \\
\hline Basic Metals \& Fabricated Metal Products & 1,310 & 1,230 & 1,191 & 1,382 & 1,528 & 1,616 & 1,824 & 1,871 & 1,984 \\
\hline \multicolumn{10}{|l|}{ And other Machinery and Equipment } \\
\hline Electrical \& Optical Equip. & 4,138 & 4,305 & 5,621 & 6,715 & 9,283 & 10,341 & 12,861 & 16,612 & 20,074 \\
\hline Transport Equipment & 181 & 174 & 168 & 189 & 203 & 234 & 324 & 558 & 562 \\
\hline Other Manufacturing inc. R \& P and & 736 & 800 & 747 & 820 & 867 & 899 & 948 & 998 & 1110 \\
\hline \multicolumn{10}{|l|}{ Coke and Petroleum Products } \\
\hline Total Manufacturing & 13157 & 14532 & 16497 & 19389 & 23199 & 25301 & 29797 & 39620 & 45767 \\
\hline \multicolumn{10}{|c|}{ B. Northern Ireland Export Sales (£Stg million) } \\
\hline Food, Drink \& Tobacco & 1283 & 1323 & 1372 & 1401 & 1566 & 1483 & 1588 & 1657 & 1939 \\
\hline Textiles, Clothing \& Leather & 718 & 755 & 837 & 898 & 999 & 1040 & 1031 & 967 & 847 \\
\hline Chemicals \& Man-made Fibres & 376 & 417 & 387 & 427 & 471 & 450 & 438 & 399 & 393 \\
\hline Basic Metals \& Fabricated Metal Products & 330 & 360 & 536 & 646 & 670 & 641 & 668 & 705 & 691 \\
\hline \multicolumn{10}{|l|}{ And other Machinery and Equipment } \\
\hline Electrical \& Optical Equip. & 338 & 368 & 445 & 530 & 653 & 767 & 842 & 1025 & 1297 \\
\hline Transport Equipment & 619 & 638 & 528 & 612 & 673 & 751 & 917 & 1017 & 1206 \\
\hline $\begin{array}{l}\text { Other Manufacturing inc. R \& P and } \\
\text { Coke and Petroleum Products }\end{array}$ & 508 & 542 & 585 & 704 & 792 & 834 & 849 & 916 & 997 \\
\hline Total Manufacturing & 4172 & 4402 & 4689 & 5217 & 5824 & 5967 & 6333 & 6686 & 7370 \\
\hline
\end{tabular}


Table A3: Real Export Series for Northern Ireland and Ireland: 1991-99

\begin{tabular}{|c|c|c|c|c|c|c|c|c|c|}
\hline & 1991 & 1992 & 1993 & 1994 & 1995 & 1996 & 1997 & 1998 & 1999 \\
\hline \multicolumn{10}{|l|}{ A. Ireland (£IR95 million) } \\
\hline Food, Drink and Tobacco & 3538 & 4376 & 4293 & 4723 & 5252 & 4640 & 4094 & 4311 & 4587 \\
\hline Textiles, Clothing and Leather & 964 & 1026 & 905 & 1034 & 1027 & 1031 & 1010 & 1017 & 890 \\
\hline Chemicals \& Man-made Fibres & 2731 & 3376 & 3725 & 4716 & 5038 & 6614 & 8653 & 13645 & 15793 \\
\hline $\begin{array}{l}\text { Basic Metals \& Fabricated Metal Products } \\
\text { and other Machinery and Equipment }\end{array}$ & 1395 & 1346 & 1211 & 1407 & 1528 & 1626 & 1813 & 1813 & 1915 \\
\hline Electrical \& Optical Equip. & 4407 & 4710 & 5718 & 6838 & 9283 & 10403 & 12785 & 16097 & 19377 \\
\hline Transport Equipment & 193 & 190 & 171 & 192 & 203 & 235 & 322 & 541 & 543 \\
\hline $\begin{array}{l}\text { Other Manufacturing inc. R \& P and } \\
\text { Coke and Petroleum Products }\end{array}$ & 784 & 875 & 760 & 835 & 867 & 904 & 942 & 967 & 1071 \\
\hline Total Manufacturing & 14012 & 15899 & 16782 & 19744 & 23199 & 25454 & 29619 & 38391 & 44177 \\
\hline \multicolumn{10}{|l|}{ B. Northern Ireland (£Stg95 million) } \\
\hline Food, Drink \& Tobacco & 1549 & 1565 & 1444 & 1445 & 1566 & 1472 & 1668 & 1835 & 2159 \\
\hline Textiles, Clothing \& Leather & 867 & 893 & 881 & 927 & 999 & 1032 & 1083 & 1071 & 943 \\
\hline Chemicals \& Man-made Fibres & 454 & 494 & 408 & 441 & 471 & 447 & 460 & 442 & 438 \\
\hline Basic Metals \& Fabricated Metal Products & 399 & 426 & 564 & 667 & 670 & 635 & 702 & 781 & 769 \\
\hline And other Machinery and Equipment & & & & & & & & & \\
\hline Electrical \& Optical Equip. & 408 & 435 & 468 & 547 & 653 & 761 & 885 & 1135 & 1444 \\
\hline Transport Equipment & 748 & 755 & 556 & 632 & 673 & 745 & 964 & 1126 & 1343 \\
\hline $\begin{array}{l}\text { Other Manufacturing inc. R \& P and } \\
\text { Coke and Petroleum Products }\end{array}$ & 614 & 641 & 615 & 726 & 792 & 827 & 892 & 1014 & 1110 \\
\hline Total Manufacturing & 5039 & 5209 & 4936 & 5384 & 5824 & 5920 & 6652 & 7404 & 8207 \\
\hline
\end{tabular}




\section{References}

Anderton B (1999) 'UK trade performance and the role of product quality, innovation and hysteresis: some preliminary results', Scottish Journal of Political Economy, 46, 570-595

Anderton B (1999a) 'Innovation, product quality, variety, and trade performance: an empirical analysis of Germany and the UK, Oxford Economic Papers, 51, 152-167.

Baltagi B H (1995) Econometric Analysis of Panel Data, Wiley.

Barry F (1999) ‘Understanding Ireland’s Economic Growth’, Macmillan, London.

Barry F and Bradley J (1997) 'FDI and Trade: The Irish Host-Country Experience', Economic Journal, 107, November 1798-1811.

Bell J (1997) 'The Role of Export Promotion Organisations' in 'Competing From the Periphery’, Fynes, B and Ennis, S (Eds.), Oaktree Press, Dublin.

Bernard A B and Jensen J B (1999) 'Exceptional export performance: cause, effect, or both?' Journal of International Economics, 47, 1-25.

Bernard A B and Wagner J (1997) 'Exports and success in German manufacturing' Weltwirtschaftliches Archiv, 133, 134-157.

Bleaney M and Wakelin K (2002) 'Efficiency, innovation and exports' Oxford Bulletin of Economics and Statistics, 64, 3-15.

Braunerhjelm P (1996) 'The relation between firm-specific intangibles and exports', Economics Letters, 53, 213-219.

Buxton T, Mayes D and Murfin A (1991) 'UK Trade Performance and R\&D', Economics of Innovation and New Technology, 1, 243-256

Coe N (1997) 'US Transnationals and the Irish Software Industry', European Urban and Regional Studies, 4, 3, 211-230.

Crone M (1998) 'Inward Investment and External Ownership in Northern Ireland Manufacturing: Historical Trends and Recent Developments', mimeo, NIERC.

Crone M (2000) 'Computer Services and Software Employment in the UK and Ireland', 1991-97, NIERC Report No 16.

Demick D H and O'Reilly A J (2000) 'Supporting SME Internationalisation: A Collaborative Project for Accelerated Export Development', Irish Marketing Review, $13,1,34-45$.

Fielding, D (2003) 'Investment, Employment and Political Conflict in Northern Ireland', Oxford Economic Papers, 55, 512-535. 
Foley A, Griffith B (1992) 'Indigenous Manufacturing Enterprises In A Peripheral Economy And The Single Market - The Case Of The Republic-Of-Ireland', Regional Studies, 26, 4, 375-386.

Forfás (2000) 'International Trade and Investment Report, 2000', Report by Forfás to the Trade Advisory Forum and the Foreign Earnings Committee, December, Dublin.

Görg H and Ruane F (2000) 'An Analysis of Backward Linkages in the Irish Electronics Sector', The Economic and Social Review, 31, 3, 215-235.

Gray A (1997) 'International Perspectives on the Irish Economy', Indecon, Dublin.

Greene, W. H., (1999). Econometric Analysis. Macmillan, New York

Greene W H (2002) LIMDEP Version 8.0: Econometric Modelling Guide, Econometric Software Inc, Plainview NY.

Greenhalgh (1990) 'Innovation and Trade Performance in the UK', Economic Journal, 100, 105-118.

Harris, R I D, Trainor, M Roper, S and Hart, M (2002) 'Evaluation of the Effectiveness of Financial Assistance to Industry', Final Report to Department of Enterprise Trade and Investment, Belfast.

Kleinknecht A (1987) 'Measuring R\&D in Small Firms: How Much are we Missing?', Journal of Industrial Economics, 36, 253-256.

Kleinknecht A (1989) 'Firm Size and Innovation: Observations in Dutch Manufacturing Industries', Small Business Economics, 215-222.

Kleinknecht A, Poot T P and Reijnen O N (1991) 'Formal and Informal R\&D and Firm Size: Survey Results from the Netherlands', in Innovation and Technical Change, Acs, Z J and Audretsch, D B (eds), Harvester Wheatsheaf, Hemel Hempstead.

Kumar N and Siddharthan N S (1994) 'Technology, Firm Size and Export Behaviour in Developing Countries', Journal of Development Studies, 32, 288-309.

Mackinnon I (1997) 'Using Young Blood to Revive Export Business', People Management, 3, 16, 40-41.

McCarthy J (1999) 'Foreign Direct Investment: An Overview', Central Bank of Ireland, Autumn, 55-65.

Metcalfe S (1997) 'Technology Systems and Technology Policy in an Evolutionary Framework', in Technology, Globalisation and Economic Performance, Archibugi D and Michie J (eds), Cambridge University Press. 
Murphy A E (2000) 'The Celtic Tiger - An Analysis of Ireland's Economic Growth Performance', Robert Schuman Centre for Advanced Studies EUI Working Paper 2000/16.

Nelson R R (1993) 'National Innovation Systems: A Comparative Analysis', Oxford University Press.

O’Malley, E (1998) 'The Revival of Irish Indigenous Industry 1987-1997', Quarterly Economic Commentary, April 1998, ESRI, Dublin.

Roper S and Anderson J (2000) 'Innovation and E-Commerce - A Cross-Border Comparison of Irish Manufacturing Plants', NIERC Research Report 17. Available at: www.qub.ac.uk/nierc

Roper S and Hewitt-Dundas N (1998) 'Innovation, Networks and the Diffusion of Manufacturing Best Practice', NIERC Research Report 14, April, NIERC, Belfast. Available at: www.qub.ac.uk/nierc

Roper, S and Hewitt-Dundas, N (2001) 'Grant Assistance and Small Firm Development in Northern Ireland and the Republic of Ireland', Scottish Journal of Political Economy, 48, 1, 99-117.

Roper, S Hewitt-Dundas, N and Savage, M (2002) 'Benchmarking Innovation Performance in Ireland's Three NUTS 2 Regions', NIERC Working Paper 76, Belfast.

Roper S and Frenkel A (2000) 'Different Paths to Success? The Electronics Industry in Israel and Ireland', Environment and Planning C, 18, 651-665.

Roper S and Love J H (2001) 'The determinants of export performance: panel data evidence for Irish manufacturing plants’ NIERC Working Paper 69, Belfast.

Roper S and Love J H (2002) 'Innovation and Export Performance: Evidence from UK and German Manufacturing Plants', Research Policy, 31, 1087-1102.

Roper S, Ashcroft B, Love J H, Dunlop S, Vogler-Ludwig K and Hofmann H (1996) 'Product Innovation and Development in UK, German and Irish Manufacturing Firms', NIERC/Fraser of Allander Institute.

Ruane F and Görg H (1997) 'The Impact of Foreign Direct Investment on Sectoral Adjustment in the Irish Economy', National Institute Economic Review, 2, 76-86.

Seringhaus F H R (1986) 'The Impact of Government Export Marketing Assistance', International Marketing Review, 3,2, 55-65.

Seringhaus F H R and Rossen P J (1990) 'Government Export Promotion: A Global Perspective', Routledge, London. 
Sterlacchini A (1999) 'Do innovative activities matter to small firms in non-R\&Dintensive industries? An application to export performance', Research Policy, 28, 819-832.

Sweeney P (1998) 'The Celtic Tiger - Ireland's Economic Miracle Explained', Oak Tree Press, Dublin.

Thirwall A (1986) Balance of Payments Theory and the UK Experience, Macmillan, London.

Veall M R and Zimmermann K F (1994) 'Goodness of fit measures in the Tobit model', Oxford Bulletin of Economics and Statistics, 56, 485-99.

Veugelers R and Cassiman B (1999) 'Make and buy in innovation strategies: evidence from Belgian manufacturing firms', Research Policy, 28, 63-80.

Wagner J (1995) 'Exports, firm size, and firm dynamics', Small Business Economics, 7, 29-39.

Wakelin K (1998) 'The role of innovation in bilateral OECD trade performance', Applied Economics, 30, 1335-1346

Wakelin K (1998a) 'Innovation and Export Behaviour at the Firm Level', Research Policy, 26, 829-841.

Willmore L (1992) 'Transnationals and Foreign Trade: Evidence from Brazil', Journal of Development Studies, 28, 314-335.

Wrynn J (1997) 'Foreign Direct Investment to a Peripheral Country - The Case of Ireland' in Fynes, B and Ennis, S (eds) 'Competing From the Periphery', Oaktree Press, Dublin.

Yearly S (1995) 'From One Dependency to Another: The Political Economy of Science Policy in the Irish Republic in the Second Half of the Twentieth Century, Science, Technology and Human Values, 20, 2, 171-196. 